\title{
Pedagogical translation: A Didactic Proposal in the EFL Classroom to Teach Grammar by means of Subtitling
}

La traducción pedagógica: una propuesta didáctica en la clase de inǵlés como lenǵua extranjera para la enseñanza de gramática mediante la subtitulación

Itzulpen pedagogikoa: proposamen didaktikoa ingelesa atzerriko hizkuntza gisa ematen den klasean, gramatika azpitituluen bidez irakasteko

\author{
Eneko García Jaurena \\ Universidad Pública de Navarra \\ enekogarciaj@gmail.com \\ Edurne Goñi Alsúa \\ Universidad Pública de Navarra \\ edurne.goni@unavarra.es \\ https://orcid.org/0000-0002-7488-2689
}

Recibido / Noiz jaso den: 30/06/2021

Aceptado / Noiz onartu den: 23/10/2021

\section{Abstract}

The objective of this paper is the presentation of a didactic proposal in which the pedagogical translation, put into practice by means of a subtitling tool, was used to teach the Simple Past in a L2 class of English in the first year of secondary education.

Two groups of students (control and experimental) studied the tense in two different ways, the first by means of the usual pedagogy, based on the textbook, and the second by means of a subtitling program, The Clip Flair Proyect, in which the students had to subtitle some oral extracts of the film Kung-Fu Panda.

As a conclusion, we can mention that the pedagogical translation does not go to the detriment of the process of learning the $L 2$ although we consider that we need more research on this topic, as this study was deeply affected by the confinement due to the COVID-19.

\section{Keywords}

Subtitling; pedagogical translation; ESL; The Clip Flair Proyect; COVID-19.

\section{Summary}

1. Introduction. 2. Literature ReVIEW. 2.1. The Use the L1 in the ESL Classroom. 2.2. The Use of Pedagogical Translation in EFL Classroom. 3. THE PROJECT. 3.1. Research Question. 3.2. Participants, Procedure, Instruments and Data Collection. 3.3. Results and Discussion. 4. PedAgogical IMPLiCATIONS. 5. CONCLUSION. REFERENCES. WEBgRAFY. ANNEXES 
Resumen. El objetivo de este trabajo es presentar una propuesta didáctica en la que la traducción pedagógica, puesta en práctica mediante un programa de subtitulación, se puso al servicio de la enseñanza del pasado simple en un aula de inglés $1 .^{\circ}$ de Enseñanza Secundaria Obligatoria

Dos grupos de alumnos (experimental y de control) trabajaron el tiempo verbal de manera diferente, el primero siguiendo la pedagogía habitual del aula, basada en la explotación del libro de texto, y el otro por medio de un programa de subtitulación, The Clip Flair Proyect, mediante el cual debían subtitular una serie de extractos orales de la película Kung-Fu Panda.

Como conclusiones, podemos apuntar que la traducción no va en detrimento del aprendizaje de la L2, aunque se necesitarían más estudios, ya que este se vio afectado profundamente por el confinamiento debido a la COVID-19.

Palabras clave. Subtitulación; traducción pedagógica; ESL; The Clip Flair Proyect; COVID-19.
Laburpena. Lan honen helburua da proposamen didaktiko bat aurkeztea. Proposamen horretan itzulpen pedagogikoa, azpitituluen programa baten bidez praktikan jarria, Iraganaldi Sinplearen irakasteko erabili zen Derrigorrezko Bigarren Hezkuntzako 1. ikasmailako ingeleseko gela batean.

$\mathrm{Bi}$ ikasle taldek (esperimentala eta kontrolekoa) beste modu batera landu zuten aditz denbora: lehenak ikasgelako ohiko pedagogia baliatuz, hots, testuliburuan oinarritua, eta besteak azpitituludun programa bat baliatuz, The Clip Flair Proyect, zeinaren bidez Kung-Fu Panda filmeko ahozko pasarte batzuei azpitituluak jarri behar baitzizkieten.

Ondorio gisa, esaten ahal dugu itzulpena ez doala bigarren hizkuntza ikastearen aurka, baina azterketa gehiago egin beharko lirateke, azterketa horretan eragin handia izan baitzuen COVID-19a dela-eta egindako itxialdiak.

Gako hitzak. Azpitituluak; itzulpen pedagogikoa; ESL; The Clip Flair Proyect; COVID-19.

\section{Introduction}

The present study focuses on the use of the mother tongue (L1 henceforth) and pedagogical translation (PT onwards) as tools which facilitate or help the process of acquisition of the second language (L2 hereafter), centring its aims on the use of translation, a contrasting method, as an instrument, which can be implemented to acquire the language.

The first part (chapter 2) consists of different theories regarding the use of the L1, the inclusion of PT and the use of subtitling in the class of English as second language (ESL onwards). After that (chapter 3), we will explain the methodology of the investigation framed with two classes of students of the first year of secondary education who, divided into the experimental and the control group, developed the project in which the translation of subtitles assisted in the process of teaching-learning of the Simple Past tense. In chapter 4, we will show the results of the study, which cannot be counted as representative, due to the problems that students had to face because of the COVID-19 confinement. To finish with, in chapters 5 and 6 we will show the conclusions which we have reached, and the pedagogical implications of the proposal. 


\section{Literature Review}

Since the development of the active methodologies, based on the communicative teaching of the $\mathrm{L} 2$, one of the most common scenarios has been the rejection of the use of the L1 and the translation in the language classes. Nevertheless, in the last years, a wide range of scholars has researched about the use of both, the L1 and the PT, in ESL. Together with this, we are witnessing the increase in the use of dubbing programs, which, based on direct and indirect translation, are being used as tools in the process of teaching and learning.

\subsection{The Use the L1 in the ESL Classroom}

In Spain, the Royal Decree 24/2015 of the $22^{\text {nd }}$ of April, which follows the guidelines stated by the Council of Europe, that underline the necessity of developing the linguistic competence, states that the second language learning process must be as similar as possible to the L1 acquisition process, in order to get natural results, which are directly applicable to the linguistic use in the real world situations $^{1}$. To achieve this aim, the Decree dictates that both, teachers and students, must use the L2, English in our case, as the vehicular language, and that classes must focus on the communicative skills, i.e., listening and speaking.

Opposing to what could be expected, this tendency originated in the past, along the $19^{\text {th }}$ century, with the development of the active methodologies for the teaching of modern languages, which left behind the use of the Grammar-translation Method, as this focused on the written skills, reading and writing. Along the last century, English as a foreign language (EFL hereafter) classes have focused on the communicative aspect and, nowadays, many educational models have been designed to immerse students in the L2. Nevertheless, there have always been voices within the educational realm who consider that the use of the L1 can also become another useful didactic tool for the EFL learning process.

\subsubsection{Arguments against the Use of the L1}

When we pay attention to the different methods developed for language teaching, we can observe that most of those based on communication reject the

1 «El aprendizaje de las segundas lenguas debe aproximarse al proceso de adquisición de las lenguas maternas para producir unos resultados de carácter natural y directamente aplicables al uso lingüuístico en el mundo real» (Royal Decree 24/2015 of 22 $2^{\text {nd }}$ of April, p. 2). 
use of the L1 as the learning of the L2 will be more effective because the use of the L1 «would cause the formation of bad habits and interfere the methodology banishing all forms of language processing»(Yavuz, 2012, p. 4340).

One of the most important events for the development of the monolingual teaching theory was the congress on English teaching held in Uganda in 1961. Phillipson (1992) listed some of the main ideas of the conference, which became the pillars of English teaching, ideas that conveyed the rejection of the L1 almost automatically. According to him, the best way to teach English is with a native English speaker by only using the L2 as, if more than one language is used, the level of English will decrease considerably. This is due to the fact that, as Cook claims «the learning of a first language is not simply a matter of learning syntax and vocabulary; rather it is environmental and linguistic as well as emotional» (Yavuz, 2012, p. 4341).

In this line, Auerbach (1993) or Cook (2001) defended the importance of the immersion in the target language. Auerbach (1993) pointed that the more the students are exposed to the L2, the faster they will acquire it and think in that language; together with this, she maintains that the only way of making students learn the language is by encouraging them to use it. Auerbach also talks about the natural transition from L1 to L2, which means that the immersion in the L2 should not be immediate, but progressive. She explains that the L1 works as «a natural bridge for overcoming problems of vocabulary, sentence structure and language confidence» (1993, p. 18). Cook (2001) is of the same opinion, when he explains that the process of acquisition of the L2 should be similar to the acquisition of the mother language and that developing the communicative skills is the most important part of EFL classes, consequently, teachers should provide students with as much input as they could. Thus, Cook defends that no other linguistic system should work as a mediator in a language acquisition process.

Likewise, other variables like the economic reasons need to be considered. Martín (2004) explains that, along the seventies and the eighties, relevant publishers decided to start producing the textbooks only in the L2, this way, those companies were able to economically profit from the global market. Non-native teachers started using these monolingual materials as they assumed, almost automatically and uncritically, that textbooks, which came from the outside, had to be necessarily better than materials produced at home.

Nonetheless, in the last years we are witnessing a spread on the studies which delve into this topic, from the point of view of the real in-class use of the L1 and the L2, to show how and under what circumstances teachers use both of them, and the general trend is the no rejection to the use of the L1 in the classroom. 


\subsubsection{Arguments for the Use of the L1}

Regarding the literature in favour of the use of the L1, many have been the scholars who have presented positive views about its maintenance in the classrooms. Henceforth, we would like to mention but a few of them.

At the end of the last century, Brooks and Donato (1994), Antón and DiCamilla (1999) or Swain and Lapkin (2000) suggested in their works that the L1 is convenient, as it supports the process of the learning of the L2 in a cognitive way, what allows the students to operate in a higher level. Gabrielatos (2001), after having analysed the progress of language learning from Latin and Greek to modern languages, opened the linguistic range and explained that contrasting (in his case by using translation) is useful not only to compare the grammar, but also the semantic, pragmatic and discursive elements of the language. The author settled that contrasting may help students to increase their comprehension level.

Macaro (2003), on the other hand, focused on the students and the development of the classes, concluding that forbidding the use of the L1 could lead to several problems, such as the lack of authority of the teacher, or obstacles in the oral interactions of the students. He also explained that monolingual teaching would have negative effects on students of lower level, defending that the appearance of the L1 should be higher in the first stages, as well.

Additionally, centring on the use of L1 as a tool for students to compare and contrast the L1 and L2, authors such as Chen (2006) claimed that the use of the contrastive analysis may help students to be aware of the risks of literal translation or of the use of false friends. Moreover, contrasting both languages may be beneficial to raise cultural awareness, being a process not only helpful for learners, but also for teachers, as these can distinguish the most difficult aspects of the learning process. The author concludes that this practice «may help learners reduce interference from their first language» $(2006$, p. 76), which is one of the most recurrent problems in ESL classrooms.

Juárez and Oxbrow (2008) explored the uses for which the L1 should be intended and explained that some scholars have suggested that teachers should use the L1 in limited doses and for procedural and managerial aspects: to set up tasks, to monitor pair and group work, to give instructions, or to check comprehension. To this list, Juárez and Oxbrow (2008) also propose to use the L1 when explaining difficult concepts and the rationale of language learning activities and, more specifically, to raise the confidence of the students. In this trend, Cummins (2007) suggested some bilingual instructional strategies to complement the monolingual teaching approaches in the L2 classes.

On the other hand, Nordin, Ali, Zubir and Sadjirin (2013) focused on the students' opinion, attitudes and usage of code switching in the L2 classroom. For this, they passed a questionnaire to forty-five diploma students from whose re- 
sults they concluded that code switching helped them to understand the L2, and that it helped «students feel more confident and comfortable» (p. 486).

In addition, Barrientos (2015), by centring on the weak students, explained that although the influence of the L1 over the L2 may be seen as an obstacle, the direct linguistic immersion with students of lower levels may lead on frustration and on rejection to the L2, which may hinder the learning process. Consequently, Barrientos explains, this process should be done progressively.

The last scholar to mention is Afriani (2020), who has also developed descriptive qualitative research to investigate on the teachers' perceptions towards the use of code switching by means of a questionnaire. The data shows that teachers are positive towards the code switching for they believe that, with a limited use, it helps them to elicit content, show interpersonal relations and manage the students.

We would not like to finish this chapter without mentioning a metaphor presented by Juárez and Oxbrow «the mother tongue is the womb from which the second language is born» $(2008$, p. 120).

\subsection{The Use of Pedagogical Translation in EFL Classroom}

\subsubsection{Pedagogical Translation}

Although translation has been the preferred method applied to the learning of both dead and modern languages throughout history, its use in EFL classroom has been criticised and many times rejected in the last decades, due to its extensive use in the Grammar-Translation method (Gasca, 2017a). When the Direct method and the Communicative approach appeared, scholars found that PT was inadequate and even counterproductive in the process of learning a new language. However, the use of the PT in ESL classrooms has experienced a resurrection in the last years, being still subject to controversy, tough.

The research on this topic is not new. Carreres, Muñoz-Calvo and Noriega-Sánchez (2017) explain how several scholars such as House (1977), Königs (1981), Titford and Hieke (1985), House and Blum-Kulka (1986), Tudor (1987), Duff (1989) or the British Council et al. (1991) defended the use of the PT in the classrooms. Nowadays, they claim, we can appreciate the renewal of the use of the PT in the classrooms, and different studies on this method have been published by scholars such as Nord (1991), Königs (2001), Laufer and Girsai (2008), Butzkamm and Caldwell (2009), House (2009), Cook (2010), Leonardi (2010), Carreres and Noriega-Sánchez (2011), Leonardi (2011), Pym (2011), Pintado-Gutiérrez (2012a), Pym, Malkmkjaer and Gutierrez Colón (2013), Carreres (2014), Kerr (2014), Laviosa (2014a, 2014b); list to which we can add the already mentioned Carreres, Muñoz-Calvo and Noriega-Sánchez (2017), Gasca (2017b), 
Navidian et al. (2019), Siregar (2019), Díaz Alarcón and Bolaños García-Escribano (2020), Escribano Sabio (2020) or Gunawan (2020).

In 2001, García Medall exposed six favourable theses towards the use of PT in the ESL classrooms, following six different scholars (Rivers and Temperley, 1978; Gibert, 1989; Arbuckle, 1990; Viqueira, 1992; Thomas, 1995; de Arriba García, 1996a and b; Pegenaute, 1996; Valero-Garcés, 1996; and Süss, 1997). According to him, PT is valid in itself, as it is a self-sufficient intellectual activity, it is an assessment tool for the communicative competence both in L1 and in L2, it is a valuable corpus for the contrastive linguistic study and, to finish with, it is a pedagogical and didactic tool for the L1 and L2.

In 2002, Guierden defined the main aspects that frame the PT. For her, it is another tool in the process of learning a language, which can be applied in all phases and levels, for questions of language contrasting. PT holds two aspects, on the one hand, the direct translation, which is an auxiliary strategy to verify and review the comprehension of the students; and, on the other, the indirect translation, which is a resource intended to activate the productive mechanisms in the different areas of the language: morphology, lexis, phraseology and syntax.

Cuéllar (2004), after analysing the use of PT activities in eleven contemporary manuals on foreign language teaching, explained that translation could be utilized as a way to access to the meaning of the elements in the L2. She observed that these activities were related not only to text comprehension, but also to the communicative approach, and that they did not only focus on language, but also on raising the motivation of the students, making them reflect on the language learning process and giving them tips to improve it and to develop learning strategies. In addition, the aim of bilingual activities was not only for students to develop the linguistic competence, but also the discursive, strategic and sociolinguistic competences, which are the ones mentioned nowadays in the Royal Decree 24/2015.

According to Churches (2009), translation may help students to develop some of the skills presented in the taxonomy of Bloom, taxonomy that classifies into six levels the skills and goals, which all students should develop in the learning process. The traditional methods usually focus on the development of the first two levels, i.e., remembering and understanding, while the new methodologies try to work on all the levels. Translation, as a contrasting tool, could be part of the fourth level, «analysing». Following this scholar, this level includes skills like «comparing», «contrasting», «organizing» or «attributing». A task with the objective of contrasting the language would help students to develop this ability and apply it to other activities or situations, this way, it can also be included in the upper level, «creating», for students are using the language to create something; consequently, they accomplish the most important step in the learning process.

Additionally, in that very year, we count on with the work of Sánchez Iglesias, who concluded it with two important claims. On the one hand, PT is a valid tool 
whenever the teacher is able to integrate it in a didactic sequence in a natural and relevant way; on the other, translation is the frame where the teacher can put into practice all the elements that feature a text: formal, lexical, semantic, textual-discursive and stylistic.

After developing some intensive research, Pym, Malmkjaer and Gutiérrez-Colón (2013) reached the conclusion that «the question is no longer whether or not translation should be used in the L2 class, but how it can be used effectively and creatively» (2013, p. 125). The authors explained that PT is not usually seen as a language-learning method in itself, but as one kind of activity among many others. In this work, they also proposed a set of different kinds of activities classified in distinct categories such as group works, comparison works or project works. In their words: «these activities seek to stress that translation can be used in ways that are communicative (...), adaptable to new technologies, and possible in situations where there are multiple L1s in the classroom» (2013, p. 125). With their work, these scholars pointed that translation activities work on the communicative competence and presented an important realm, the new technologies.

More recently, Gasca (2017a) focused on the development of accuracy by means of a study with native learners of Spanish. She concluded that PT has a positive impact on the accuracy of the L2 of the learners as, thanks to the contrastive exercises, they developed the ability to find the exact voice or structure in the L2. She also proposed to use reverse translation (L1> L2) activities to develop grammatical precision.

We would like to finish with Carreres, Muñoz-Calvo and Noriega-Sánchez (2017) who have linked PT with the new commands of the European Union. According to them, with the introduction of the concept of mediation (mediation defined as all those activities intended to ease the communication when this faces obstacles that make it difficult), the European Framework of Reference lays the foundations for the normalization and the integration of translation in the process of teaching learning of the L2.

\subsubsection{Translation and New Technologies in the EFL Classroom}

Throughout the years, the use of PT in teaching contexts has generally been text-based. However, since the inclusion of the information and communication technologies (henceforth ICT) in the curriculum, the use of other more modern specialities, like subtitling or dubbing, have also gained popularity and studies linking both have increased. Carreres, Muñoz-Calvo and Noriega-Sánchez (2017) cite three main areas of investigation: the first is based on the corpus (Zanettin, 2001 and 2009; Rabadán and Fernández Nistal, 2002; Ilisei, Pekar and Bernardini, 2009), the second is the automatic translation (Niño, 2009; Merschel et 
al., 2013) or gamification (Wang and Seneff, 2007; Figueroa Flores, 2015; Osipov et al., 2015), and the third focuses on the applications of audio-visual translation in the pedagogy of languages, or PT (Díaz Cintas, 2012, who developed the concept of «didactic subtitle»; Talaván, 2013; Incalcaterra \& Lertola, 2014; Talaván and Rodríguez-Arancón, 2014; Álvarez, 2017; Reig, 2017; Castro, 2021), in which we include this study.

It is a fact that the combination of ICT and PT provides teachers with innumerable opportunities to develop new methodologies in the ESL classroom. Vermeulen (2004) claims that, when using audio-visual translation in the classroom, the text of this audio-visual multimedia and its translation (both dubbing and subtitling) are a perfect tool to broad any kind of learning related topies, and to improve the students' language and the conscience of the sociocultural context in which the language develops. In this line, Baños and Sokoli (2015) cite Talaván Zanón (2013) to summarise the most relevant benefits of integrating audio-visual material in ESL:

It introduces variety and creates an interactive and entertaining learning environment, thus increasing students' motivation; it provides exposure to nonverbal cultural elements and presents authentic linguistic and cultural aspects of communication in context; it is extremely flexible and can be adapted according to the needs of students and tutors; it promotes transferrable skills; and students can be easily encouraged to use this type of material when learning a language independently (pp. 52-53).

Focusing on the Spanish legislation, audio-visual translation can become a useful tool to develop some of the key competences of the LOMCE as, according to authors like Vermeulen (2004), Caimi (2006), Borghetti (2011), Vigata (2011), McLoughlin and Lertola (2014) or Wang (2014), this new type of translation goes beyond the text itself, and involves other elements as context, ICT or cultural features. Thus, these activities can enhance, apart from the Competence in Linguistic Communication, other competences such as the Digital Competence, the Learning to Learn Competence, the Social and Civic Competences, the Sense of Initiative and Entrepreneurship and the Cultural Awareness and Expression Competence.

\subsubsection{The Use of Subtitling in the EFL Classroom: The Clip Flair Project as a Model}

Along the last decade, scholars have developed numerous investigations on the use of subtitling, the different ways to apply this practice in the classroom, and the multiple activities that can be created for ESL classes, activities, which will depend on the goal of the teachers and the needs and level of the students. 
In 2008, Bianchi and Cibattoni framed a study with 107 students divided into 3 groups: the control group, the group that used traditional subtitles and the one that used bimodal subtitles. The results showed that the students who used traditional subtitles obtained higher marks on comprehension than the other two groups. In addition, this group had better results in vocabulary comprehension, comparing to the group which used bimodal subtitles.

Another example comes from Talaván (2012), who explained that traditional subtitles (audio in L2 and subtitles in L1) should be used, as a rule, with levels A1-B2 to facilitate the understanding of the audio-visual document. With initial levels (A1 and A2), teachers could practise with adapted materials, depending on the capacities of the students. Instead, with advanced levels (C1 and C2), bimodal subtitles (audio and subtitles in L2) must be used in order to consolidate more complex or unknown lexical and phonetic structures.

In 2012 as well, Fazilatfar, Ghorbani and Samavarchi developed a study with 100 high school students in Iran, which centred on the acquisition of vocabulary. They divided the students into three groups: the first used reversed subtitles, the second standard subtitles and the third did not use subtitles. The results showed the higher levels of acquisition of vocabulary among the students of the first group, those who had dealt with reversed subtitles. Thus, participants showed that they «can acquire elements of a foreign language through watching subtitled television programs» (p. 58) and, more specifically, using translated subtitles.

Two years after this, in 2014, Gorjian devised a similar study on the use of subtitled movies in EFL classroom. In this case, participants were adults, but the results were very similar, what made this author claim that «human beings are able to remember $10 \%$ of what they hear, $20 \%$ of what they visually perceive, and $80 \%$ of what they visually perceive and interact with» (p. 1022).

Additionally, Zabalbeascoa, González Casillas and Pascual Herce (2015) framed a study in which, again, students worked with subtitling activities. After analysing the results, these scholars recommended the combination of audio in L2 and subtitles in L1 for students of lower level. They also explained that students at this level are able to read subtitles in their L1, but they are not as fast when reading in the $\mathrm{L} 2$. In addition, the authors explained that most of the students were able to access to both texts (English and Spanish) and compare them. Even, some students became aware of certain subtitling norms or practices, such as summarising and omissions, as well.

To finish with, Lertola (2018) collected most of the methodologies used throughout history in language learning environments, and researched about the use of translation on them, listing the following conclusions:

Besides offering the pedagogical benefits of translation, due to its multimodal nature, sub-titling allows for the development of AV skills, namely AV watching, AV listening, AV writing and, in some cases, AV reading. Furthermo- 
re, recent research has reported that subtitling fosters vocabulary acquisition, pragmatic awareness and intercultural education. Subtitling practice is a motivating activity, its time and space constraints challenge learners to avoid word for word translation and, importantly, to identify the core message to be translated. It is a task suitable in classroom and online contexts both for autonomous and collaborative learning (p. 198-199).

Although numerous studies focus on the use of subtitled materials, we consider that it might be relevant to ask students to create or translate subtitles instead of just watching them. The present work is going to take as example the Clip Flair Project, following the references of Soler (2020), which has the goal of teaching languages through subtitling and dubbing tasks. This project was created in 2011 and it is a new version of the SLL (subtitles and language learning) Project, developed in 2009, being funded by the EU. In the webpage of the Clip Flair Project they define it as «one way of working with AV material in a productive and motivating way is to ask learners to re-voice (e.g. dub) or caption (e.g. subtitle) a video clip (film scene, documentary, news piece, animation, song etc.)» (Clipflair. net.s.p.).

\section{The Project}

\subsection{Research Question}

The question, which we formulated before the research, was «Is subtitling (translation as a language contrasting tool based on the use of the L1) effective to improve the knowledge of the first year of secondary education students of the L2 - the Past Simple in our case?».

\subsection{Participants, Procedure, Instruments and Data Collection}

The research was developed in a high school in Burlada, a town close to Pamplona, in which Basque is the L1 and English is the L2. The participants were the 35 students of two groups, out of the four groups, of the first year of secondary education. It is important to note that it was the high school teacher the one who distributed the groups in an equitable way, so that the results were as accurate as possible and that, in both groups, the combination of the languages and the goals remained the same. On the other hand, the grammar to be studied was the Simple Past tense, as it was the topic scheduled by the teacher. 
Based on the methodology CAR (Cooperative, Active, Reflexive), the project consisted on a didactic proposal, in which students had to subtitle into English the dialogue of a famous film and put into practice, both orally and by means of written exercises, the tense studied. We intended the pupils to work cooperatively and actively and, by means of reflection, to be able to learn the past tense. Nevertheless, it had to be re-designed, due to the spread of COVID-19 and the subsequent confinement, which took place along March and April 2020, and adapted for its online development, what conveyed a change and reduction in the materials prepared in the first stance. As the situation took longer than expected, we had to face some problems, which affected the results. The most relevant was that although the high school provides all students with a Chromebook, not all of them could participate, due to several reasons as the lack of Internet connection at home, or the difficulties to adapt to the schedules of the other members of the families. The second was a reduction in the proposal, intended as a didactic unit, then, reduced to a proposal, as time was shortened and the oral and written performance of the use of the simple past could not be implemented and tested. The third referred to the platform for the subtitling task, Amara.org, an online platform used to create and translate subtitles. After having analysed it in depth, the teacher and the practice student decided to change it, as it works as a community, and each member has access to the work of other participants, what means that the students could accede to the work of their classmates. Thus, they decided to use another platform, Kapwing.com, which does not work as a community.

Had the proposal been implemented in class, the methodology would have been the communicative approach, with oral and written practice, but, as students were alone at home, they decided to develop a task-based approach, focusing specifically on the acquisition of the grammar. The project began with the creation of two web pages containing links to the steps one and two to guide the students in the process. The pages, which were posted in Google Classroom, gave the students access to the webpage of the group to which they belonged. The first step included an explanation file and the pre-test (see annex 1). To begin with, all students attended an initial explanation, carried out via Google Handouts Meet, in which the project was presented and briefly explained. The practice student elaborated a PDF file with the information to solve the questions, which could appear along the time. Then, all the students took the pre-test in which they had to do some exercises related with the Past Simple tense to check their previous knowledge. After that, the step two included different materials to work on the past simple (grammar explanation and written exercises); each group was divided into two (control and experimental) and they worked with the different methodologies. The control group, under the supervision of the high school teacher, followed the traditional method, with grammar explanations and exercises tak- 
en from Englisch-hilfen.de ${ }^{2}$; on the other hand, the experimental group, under the supervision of the student doing his practice period, developed the subtitling task. This second group had access to two tutorials (see annexes 2 and 3) created with screenshots to guide the process of subtitling. To finish with, the last day of the week, after both groups had completed the previous steps, the step three was enabled for them. This last part consisted of the post-test (annex 4) and the questionnaire (annexes 5 and 6). We must underline that both the pre and the post text were developed according to the needs marked by the teacher, and that, due to the situation, they were not validated by experts.

\subsection{Results and Discussion}

We would like to underline three problems, which we met. The first is that when we work with students of the first year of secondary education, especially when we use ICT, communication is very important. Even though the teacher assured that the students were skilful with technology, many errors or problems may occur and communication through online platforms is not as fast and effective as face-to-face communication. Secondly, the high school did not establish compulsory attendance to online classes therefore, from the 35 students expected, only 21 could participate in the investigation; 13 were part of the experimental group and eight were part of the control group. The third is a factor that conditioned the process: the work done by students was individual and independent. If the study had been conducted in on-site classes, teachers would have been able to help all students in their personal learning processes, nevertheless, in our case, this was very difficult to achieve. With all these factors in mind, we proceed with the results of the study.

\subsubsection{General Results}

Chart 1. Number and percentages of errors.

\begin{tabular}{|c|c|c|c|}
\hline \multicolumn{2}{|c|}{$\begin{array}{c}\text { Experimental group } \\
\text { (13 students x } 15 \text { questions) }\end{array}$} & \multicolumn{2}{|c|}{$\begin{array}{c}\text { Control group } \\
\text { (8 students } x 15 \text { questions) }\end{array}$} \\
\hline Pre-test & Post-test & Pre-test & Post-test \\
\hline $63 / 195$ & $50 / 195$ & $44 / 120$ & $38 / 120$ \\
\hline $32,3 \%$ & $25,64 \%$ & $36,67 \%$ & $31,67 \%$ \\
\hline
\end{tabular}


We should not start without mentioning that we have not used any specific tool or software to analyse the data, as preferred this way by the student.

The pre-test and the post-test consisted of three parts and fifteen questions, designed following the scholar needs marked by the class teacher. As it can be observed in the table, the percentage of error is not very high either in the pre-test or in the post-test. The teacher advised that although past tenses are supposed to be a new element to learn at this level, most of the students had already worked on them. Nevertheless, a general improvement can be appreciated from the pre-test to the post-test. Both groups did fewer mistakes in the post-test: the experimental group had an improvement of the $6,66 \%$, and in the control group the improvement was that of a $5 \%$. So, the figures reflect an upgrade of the $1,6 \%$ favourable to the experimental group, difference which is not significant.

In general, it was observed that the students who achieved good marks in the pre-test performed the same in the post-test and the ones who committed more mistakes did a little better in the post-test.

\subsubsection{Results of the First Part: Filling the Gaps}

Chart 2. Number and percentage of errors in the first part

\begin{tabular}{|c|c|c|c|c|c|c|c|c|c|c|c|c|c|}
\hline & \multicolumn{13}{|c|}{ Part 1: FILL THE GAPS } \\
\hline & \multicolumn{7}{|c|}{ Experimental } & \multicolumn{6}{|c|}{ Control } \\
\hline \multirow[t]{2}{*}{ PRE } & Q1 & Q2 & Q3 & Q4 & Q5 & \multicolumn{2}{|c|}{ Total } & Q1 & Q2 & Q3 & Q4 & Q5 & Total \\
\hline & 2 & 1 & 11 & 5 & 2 & $21 / 65$ & $32,3 \%$ & 0 & 5 & 5 & 5 & 4 & $19 / 40 \quad 47,5 \%$ \\
\hline \multirow[t]{2}{*}{ POST } & Q1 & Q2 & Q3 & Q4 & Q5 & \multicolumn{2}{|c|}{ Total } & Q1 & Q2 & Q3 & Q4 & Q5 & Total \\
\hline & 4 & 2 & 5 & 6 & 2 & $19 / 65$ & $29,23 \%$ & 4 & 3 & 2 & 4 & 2 & $15 / 40 \quad 37,5 \%$ \\
\hline
\end{tabular}

The first part of the tests consisted of five sentences with gaps to fill with a verb in simple past, being the verb to be used written at the end of the sentence in infinitive. There were regular and irregular verbs, positive and negative sentences and questions. As it can be observed, the students performed better in the posttest, but the difference is insignificant.

Questions one and three in both tests consisted of affirmative sentences which included irregular verbs. As expected, these were the questions in which students committed the most mistakes, however, thanks to the practice, students improved in the post-test. The most recurrent error is the use of the regular form with irregular verbs: "sited or "set instead of «sat», "gived instead 
of «gave» or *feeded instead of «fed», what could lead us to consider here the principle of over-regularization. We could presume that the difference may have been more sizable if the study had lasted longer; nonetheless, the table shows that both methodologies worked in similar ways in the learning of irregular verbs.

Questions two and five consisted of negative sentences with regular and irregular verbs. In this case, students performed better than with the affirmative sentences, but they still committed some mistakes. It can be observed that the students who did well in the pre-test continued alike and the students who committed mistakes in the pre-test did slightly better in the post-test. As it was expected, the recurrent errors were using the past tense in both verbs: "didn't drank instead of «didn't drink», *didn't brought instead of «didn't bring» or *didn't tried instead of «didn't try».

The exercise number four was a question. The results of the students are similar to those of the negative sentences. The experimental group did not do it better and the control group committed only one mistake less. The recurrent error, as it happened with the negation, was that students used the past tense in both verbs. For example, they wrote *did the concert started or *is the concert started instead of «did the concert start».

Once again, we would like to underline that the environment in which the research was conducted influenced the way in which students worked and their acquisition of the knowledge. The table shows that the methodology had no effect for better or worse.

In this case, the experimental group had an improvement of the 3,07\%, and in the control group the improvement was that of a $10 \%$, reflecting the figures an upgrade of the $6,93 \%$ favourable to the control group, which supposes a significant rise.

\subsubsection{Results of the Second Part: Ordering the Sentences.}

Chart 3. Number and percentage of errors in the second part

\begin{tabular}{|c|c|c|c|c|c|c|c|c|c|c|c|c|c|}
\hline & & & & & & 2: ORI & ER THE : & SENT & NCE & & & & \\
\hline & & & & perin & ental & & & & & & Cont & & \\
\hline PRE & Q1 & Q2 & Q3 & Q4 & Q5 & & tal & Q1 & Q2 & Q3 & Q4 & Q5 & Total \\
\hline & 7 & 4 & 5 & 2 & 4 & $22 / 65$ & $33,85 \%$ & 4 & 2 & 4 & 3 & 1 & $14 / 40 \quad 35 \%$ \\
\hline POST & Q1 & Q2 & Q3 & Q4 & Q5 & & tal & Q1 & Q2 & Q3 & Q4 & Q5 & Total \\
\hline & 4 & 5 & 4 & 2 & 4 & $19 / 65$ & $29,23 \%$ & 1 & 2 & 3 & 2 & 4 & $12 / 40 \quad 30 \%$ \\
\hline
\end{tabular}


In this part, students were asked to order the sentences, affirmative, negative and questions, without conjugating the verb. Again, the students who undertook these sentences well performed equally in the post-test and the students who committed mistakes did the same but with slightly fewer errors. It is not observed that the type of sentence had any influence on their performance as most of the errors were caused for they did not understand the sentence. In fact, some students did the five sentences wrong and the sentence with the most errors is, in our view, very simple: «They gave me some eggs for dinner». Knowing this, we must refer again to the influence of the situation, what conveyed the lack of motivation of the students. Nevertheless, the similar results and improvement illustrated in the table show again that the methodology did not have any effect.

In exercise 3 , the experimental group had an improvement of the $4,62 \%$, and in the control group it was a $5 \%$, being, this way, slightly superior.

\subsubsection{Results of the Third Part: Translating the Sentences}

Chart 4. Number and percentage of errors in the third part

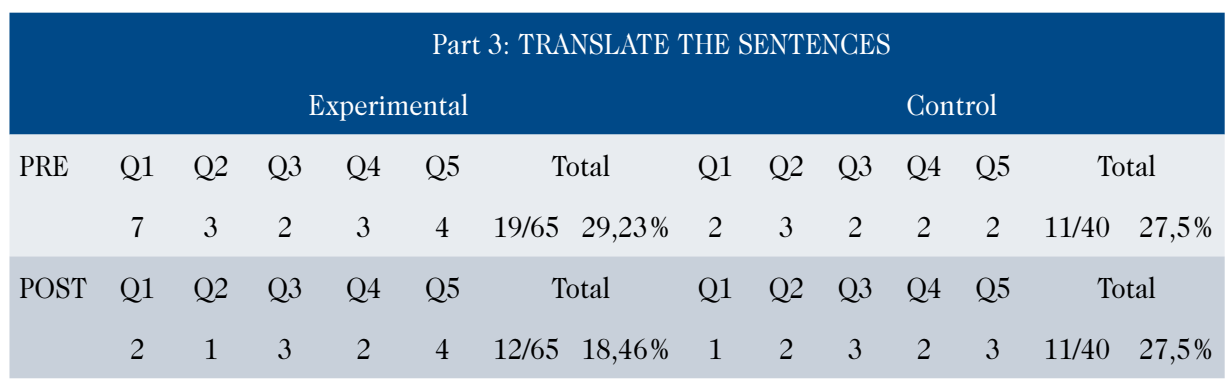

In the last part, students had to translate five sentences, affirmative, negative and questions, like in the previous exercises. The results show that the type of sentence has no apparent relation with the performance of the students. We can observe two main kinds of mistakes: on the one hand, the students not understanding the original sentence and, on the other, the students translating the verbs into the present tense, being this last one the most recurrent. For example, some students translated «was the coffee imported from China?» as "¿ies el café importado de China?» translation that could be valid in some contexts although the meaning is not exactly the same. In some other cases, like translating «she didn't know where the party was» into «no sabe dónde está la fiesta», the translation changes the meaning of the original sentence completely, thus we decided to consider them as mistakes. 
To finish with, the experimental improved in a $10,77 \%$, while the control group didn't improve $(0 \%)$. We can deduce, then, that the translation exercise helped the students in the exercise, which involved, precisely, translation. We must also mention that the control group did not do any exercises on translation, or any other activity based on the comparison between the L1 and the L2, as the teacher do not include rendering activities in his methodology. Supposedly, and seen the results of the experimental group, its inclusion in the proposed activities may have changed the results of the control group.

\subsubsection{Results of the Questionnaire}

Apart from the tests, students also completed a questionnaire about their opinion and attitude towards the methodologies with which they had worked. In this case, and for no apparent reason, only nine students from the experimental group and five from the control group answered.

The questionnaire contained eight questions. The first six questions, which are the ones to be analysed in this section, referred to their opinion on the use of different methodologies and the last two asked about their opinion on the study; out of these six questions, three were open so that students could justify their answers and the other three questions followed the Likert scale: 1: Not at all; 2: A little; 3: Neutral; 4: Very much; 5: Absolutely.

Chart 5. Number and percentages of answers to question one of the questionnaire

\begin{tabular}{|c|c|c|c|c|c|c|c|c|c|c|}
\hline \multirow{3}{*}{$\begin{array}{l}\text { Q1 } \\
\text { Answer }\end{array}$} & \multicolumn{5}{|c|}{ EXPERIMENTAL GROUP (9) } & \multicolumn{5}{|c|}{ CONTROL GROUP (5) } \\
\hline & \multicolumn{5}{|c|}{ I liked the activity } & \multicolumn{5}{|c|}{ I would like to try the subtitling task } \\
\hline & 1 & 2 & 3 & 4 & 5 & 1 & 2 & 3 & 4 & 5 \\
\hline Number of answers & 0 & 0 & 1 & 3 & 5 & 1 & 0 & 1 & 2 & 1 \\
\hline Percentage & $0 \%$ & $0 \%$ & $11,11 \%$ & $33,33 \%$ & $55,56 \%$ & $20 \%$ & $0 \%$ & $20 \%$ & $40 \%$ & $20 \%$ \\
\hline
\end{tabular}

As it can be observed in the table, students showed a truly positive response towards the subtitling task. In the experimental group, all students took pleasure in the activity, except for one student who used a neutral answer. With reference to the control group, one student answered that she would not like to perform the subtitling task, another answered «neutral» and the rest said that they would like to try it. 
The second question was a justification for the previous one: Why? / Why not? Most of the answers of the experimental group were positive and students used terms like «funny», «entertaining» or «beautiful» to justify why they had relished the activity. Some of them also mentioned that they had learned «many things» by performing the task. Regarding its difficulty, experiences differed; although most of the students found it «easy», a couple of them found it «difficult» or explained that they «didn't like the platform». As mentioned before, this could be a consequence of the situation in which the study was elaborated.

On the other hand, the control group also showed a positive attitude towards the activity and justified that it could be «more fun» than traditional exercises. The only student who answered that she would not like to try the subtitling task justified it by saying that she doesn't like subtitles.

Chart 6. Number and percentages of answers to question three of the questionnaire

\begin{tabular}{|c|c|c|c|c|c|c|c|c|c|c|}
\hline \multirow{3}{*}{$\begin{array}{l}\text { Q3 } \\
\text { Answer }\end{array}$} & \multicolumn{5}{|c|}{ EXPERIMENTAL GROUP (9) } & \multicolumn{5}{|c|}{ CONTROL GROUP (5) } \\
\hline & \multicolumn{5}{|c|}{$\begin{array}{l}\text { I would like to do more activities like this } \\
\text { in class }\end{array}$} & \multicolumn{5}{|c|}{$\begin{array}{l}\text { I would like to do activities like the } \\
\text { subtitling task in class }\end{array}$} \\
\hline & 1 & 2 & 3 & 4 & 5 & 1 & 2 & 3 & 4 & 5 \\
\hline $\begin{array}{l}\text { Number of } \\
\text { answers }\end{array}$ & 0 & 1 & 2 & 0 & 6 & 0 & 1 & 0 & 3 & 1 \\
\hline Percentage & $0 \%$ & $11,11 \%$ & $22,22 \%$ & $0 \%$ & $66,67 \%$ & $0 \%$ & $20 \%$ & $0 \%$ & $60 \%$ & $20 \%$ \\
\hline
\end{tabular}

Like in the previous questions, students, in general, showed a positive opinion about the inclusion of this variety of tasks in the classroom. In the experimental group, one student answered negatively, two «neutral» and six replied that they would «absolutely» like to add these exercises in the classroom. In the control group, only one student answered that she would not like to include subtitling in the classroom and four positively.

When asked «Why / Why not?» in question four, most of the participants of the experimental group answered again that the task was «funny» and «interesting», differing again on the difficulty of the task. The student of this group who responded negatively justified that he preferred «writing and reading exercises». The participants of the control group also claimed that it would be «funny» and one of them concluded that 'I think that it is more fun and the two ways of teaching work similarly, so I prefer the subtitling'. The student of this group who answered negatively justified it explaining that by using translation she «learns little». 
Chart 7. Number and percentages of answers to question five of the questionnaire

\begin{tabular}{|c|c|c|c|c|c|c|c|c|c|c|}
\hline \multirow[b]{2}{*}{ Q5 } & \multicolumn{5}{|c|}{ EXPERIMENTAL GROUP (9) } & \multicolumn{5}{|c|}{ CONTROL GROUP (5) } \\
\hline & & & I fe & I have le & $\mathrm{rnt} / \mathrm{prac}$ & ed th & st $\mathrm{Si}$ & & & \\
\hline Answer & 1 & 2 & 3 & 4 & 5 & 1 & 2 & 3 & 4 & 5 \\
\hline $\begin{array}{l}\text { Number of } \\
\text { answers }\end{array}$ & 0 & 0 & 1 & 3 & 5 & 0 & 0 & 2 & 2 & 1 \\
\hline Percentage & $0 \%$ & $0 \%$ & $11,11 \%$ & $33,33 \%$ & $55,56 \%$ & $0 \%$ & $0 \%$ & $40 \%$ & $40 \%$ & $20 \%$ \\
\hline
\end{tabular}

In question number five, students of both groups answered that they felt that they had learnt the past simple with their methodology. In the experimental group, eight participants answered positively and one neutrally and in the control group three positively and two neutrally. Comparing the percentages, the students of the experimental group had a more forceful answer than those in the control group. Nevertheless, the difference in the numbers is minimal and we consider that further research in normal circumstances is required.

Question six was «How do you feel about using Spanish / Basque to learn Enǵlish?». Although we expected a different result, only one student from both groups had a negative answer to this question, as 'it is not a good method to learn because sometimes we use the Spanish words in an English sentence'. Apart from this participant, the rest replied that it is «good» and «useful» and that it makes it «easier to learn». One of them also explained that this task helped her to «learn how they say some words», which emphasises the benefits of using real materials.

To finish with, to the question «Something you would like to do / practice in classes» the most recurrent proposes were including «funny things» and «games». More specifically, half of the participants mentioned «projects» and «tasks» although not translation in particular.

\section{Pedagogoical Implications}

After having analysed the use of PT in ESL classrooms, we consider that it would be beneficial to create diverse tasks that include translation, as it may facilitate the learning process of the students. In addition, the combination of PT and ICT provides teachers with numerous options of incorporating more modern translation specialties such as the audio-visual rendering. Nowadays, thanks to ICT and the Internet, it is not demanding for teachers to create and perform this kind of tasks, which are not only beneficial in the process of learning English, but also in the motivation of the students towards the ESL learning process. 
Furthermore, high schools, as it is the case of the centre in which this study was conducted, are incorporating personal Chromebooks, which make it undemanding to work with internet tools and design others in varied ways, which could fulfil the necessities of each student and those of the whole class. This way, the groupings of students can be varied; teachers can create exercises with both, direct or reverse translation; students can watch series, films or any other audio-visual material which students wish, etcetera.

In conclusion, and deduced from the results of the didactic proposal, dedicating some time in class to audio-visual translation may facilitate and/or improve the language learning process of the students.

\section{Conclusion}

Although there have been many voices which have considered the use of the L1 and the PT in the ESL classroom inadequate, through this paper, we have sought to affirm the possibility to use both procedures, with the study of the main authors in both areas and with the development of a didactic proposal in which we have linked the PT and a subtitling tool.

To begin with, this work has shown that a wide range of scholars, such as Barrientos (2015), Carreres (2017), Afriani (2020) or Gunawan (2020), defends the benefits of using the L1 and the PT with the students of ESL, drawing positive conclusions in their research. Lately, some voices have adapted to times and found that another possibility is to integrate translation and the use of ICT tools to create either subtitling or dubbing activities.

Secondly, we aimed to answer the following question: Is subtitling (translation as a language contrasting tool based on the use of the L1) effective to improve the first year of secondary education students' knowledge of the past simple? Once the results were analysed, it can be observed that both methodologies (PT and traditional teaching) worked in a similar way, as the results of both groups improved from the pre-test to the post-test, but in one case, the exercise in which students had to translate, which saw no improvement in the control group (students who had not exercised this skill). Regarding the total results, we see that the experimental group had an improvement of the $6,66 \%$, while in the control group the improvement was that of a $5 \%$. So, the figures reflect an upgrade of the $1,6 \%$ in the experimental group, which had 5 more students than the control group, what can also alter the results.

Based on this, it can be concluded that translation can be used as many other methodologies or strategies in the process of teaching learning of the grammar of the L2. In fact, and as proven, the use of translation does not seem to work to the detriment in the process of learning. Nevertheless, this proposal must be consid- 
ered just a pilot study in the developing of research, which could conclude with the creation of didactic units based on translation and subtitling since we are aware that we cannot extract conclusive results, translatable to other contexts, as the sample is exiguous and the experimentation covered but a short period. Due to this, further research with a higher number of students and on the long term will be necessary to confirm our outcomes.

\section{References}

Afriani, R. (2020). Teacher perception towards the use of code switching in efl classroom: a case study in English intensive program at state Islamic institute in cirebon. Berumpun: International Journal of Social, Politics, and Humanities, $3(1), 1-12$.

Álvarez Sánchez, P. (2017). Una imagen vale más que mil palabras: La subtitulación como recurso didáctico en el aprendizaje de lenguas. redit: Revista electrónica de didáctica de la traducción y la interpretación (11), 16-32.

Antón, M., \& Dicamilla, F. J. (1999). Socio-Cognitive Functions of L1 Collaborative Interaction in the L2 Classroom. The Modern Language Journal, 83(29), 233-247.

Auerbach, E. R. (1993). Reexamining English Only in the ESL Classroom. TESOL Quarterly, 27(1), 7-32.

Baños, R., \& Sokoli, S. (2015). Learning foreign languages with Clip Flair: Using captioning and revoicing activities to increase students' motivation and engagement. 10 years of the LLAS elearning symposium: case studies in good practice, 203213.

Barrientos Martínez, K., Fonseca Toledano, M., Ordaz Ramírez, J. A., Ortiz May, D. L., \& Sánchez Bonilla, A. E. (2015). El papel del uso de la L1 (español) en los estudiantes en el aprendizaje de una L2 (inglés), 1-17.

Bianchi, F., \& Ciabattoni, T. (2008). Captions and subtitles in EFL learning: An investigative study in a comprehensive computer environment. EUT Edizioni Università di Trieste.

Borghetti, C. (2011). Intercultural learning through subtitling: The cultural studies approach. Audio visual translation: subtitles and subtitling: theory and practice, 111-138.

Brooks, F. B., \& Donato, R. (1994). Vygotskyan Approaches to Understanding Foreign Language Learner Discourse during Communicative Tasks. Hispania, 77(2), 262-274.

Caimi, A. (2006). Audiovisual translation and language learning: The promotion of intralingual subtitles. The Journal of Specialised Translation, 6, 85-98.

Carreres, A., Muñoz-Calvo, M., \& Noriega-Sánchez, M. (2017). Translation in Spanish language teaching: the fifth skil / La traducción en la enseñanza del español: la quinta destreza. Journal of Spanish Language Teaching, 4 (2), 99-109. Retrieved from: https://doi.org/10.1080/23247797.2017.1419030 
Castro Moreno, C. (2021). La traducción y la subtitulación en el aula de idiomas. Revista de Innovación y Buenas Prácticas Docentes, 10(1), 1-14

Chen, L. (2006). The Effect of the Use of L1 in a Multimedia Tutorial on Grammar Learning: An Error Analysis of Taiwanese Beginning EFL Learners' English Essays. Asian EFL Journal, 8(2). Retrieved from: http://www.asian-efljournal.com/ June_06_llc.php

Churches, A. (2009). Taxonomía de Bloom para la era digital. Eduteka. Recuperado, 11.

Cook, V. (2001). Second Language Learning and Language Teaching. Oxford University Press.

Cuéllar Lázaro, M. D. C. (2004). Un nuevo enfoque de la traducción en la enseñanza comunicativa de las lenguas. Herméneus: Revista de la Facultad de Traducción e Interpretación de Soría (6), 41-57.

Cummins, J. (2007). Rethinking monolingual instructional strategies in multilingual classrooms. Canadian Journal of Applied Linguistics, 10(2), 221-240.

Díaz Alarcón, S., \& Bolaños García-Escribano, A. (Eds.) (2020). Taking Stock of Recent Advances in Pedagogical Translation and Foreign Language Education. e-Expert Seminar Series: Translation and Language Teaching 2, UCO Press, 271-277.

Díaz-Cintas, J. (2012). Los subtítulos y la subtitulación en la clase de lengua extranjera. Abehache: Revista da Associação Brasileira de Hispanistas, 2(3), 95-114.

Escribano Sabio, A. (2020). El papel de la traducción en el aula de ele desde la perspectiva del estudiante universitario alemán. Sabir. International Bulletin of Applied Linguistics, 1(2), 33-45.

Fazilatfar, A. M., Ghorbani, S., \& Samavarchi, L. (2012). The effect of standard and reversed subtitling versus no subtitling mode on L2 vocabulary learning. Journal of Teaching Language Skills, 3(1), 43-64.

Gabrielatos, G. (2001). L1 Use in ELT: Not a Skeleton, but a Bone of Contention. A response to Prodromou. TESOL Greece Newsletter, 70. Retrieved from: http:// www.tesolgreece.com/n1/70/7001

García-Medall, J. (2001). La traducción en la enseñanza de lenguas. Hermeneus (3), 113-140. Retrieved from: https://recyt.fecyt.es/index.php/HS/article/view/6083

Gasca Jiménez, L. (2017a). El efecto de la traducción pedagógica en la precisión morfosintáctica: un estudio preliminar con estudiantes avanzados de ESL. Revista Comunicación, 26, 2-17. Retrieved from: https://doi.org/10.18845/re. v26i2-17.3441

Gasca Jiménez, L. (2017 b). Las posibilidades de la traducción pedagógiica en la enseñanza del español como segunda lengua. Estudios de Lingüística Aplicada. Retrieved from https://doi.org/10.22201/enallt.01852647p.2017.66.837

Gierden Vega, C. (2003). La traducción pedagógica como ejercicio integrativo en la didáctica del alemán como LE. Encuentros. Revista de investigación e innovación en la clase de idiomas, 13-14, 90-100.

Gorjian, B. (2014). The effect of movie subtitling on incidental vocabulary learning among EFL learners. International Journal of Asian Social Science, 4(9), 10131026. 
Gunawan, S. A. (2020). Pedagogical Translation in Second Language Acquisition. Jurnal Basis, 7(2), 225-232. Retrieved from: http://113.212.163.133/index.php/basis/ article/view/1996.

Incalcaterra, McLoughlin, L., \& Lertola, J. (2014). Audiovisual Translation in Second Language Acquisition. Integrating subtitling in the Foreign-language Curriculum. The Interpreter and Translator Trainer, 8(1), 70-83.

Juárez, C. R., \& Oxbrow, G. (2008). L1 in the EFL classroom: More a help than a hindrance? Porta Linguarum (9), 93-109.

Leonardi, V. (2011). Pedagogical translation as a naturally-occuring cognitive and linguistic activity in foreign language learning. Sezione di Lettere, 6(1-2), 17-28.

Lertola, J. (2018). From Translation to Audiovisual Translation in Foreign Language Learning. TRANS: revista de traductología (22), 185-202.

Macaro, E. (2003). Teaching and Learning a Second Language. A Guide to Recent Research and its Applications. Continuum.

Martín Martín, J. M. (2004). Sobre lo contrastivo y el conocimiento lingüuístico previo en la enseñanza del español. La competencia lingüística y comunicativa en el aprendizaje del español como lengua extranjera. Universidad Pablo de Olavide, Edinumen, 11-23.

McLoughlin, L. I., \& Lertola, J. (2014). Audiovisual translation in second language aequisition. Integrating subtitling in the foreign-language curriculum. The Interpreter and Translator Trainer, 8(1), 70-83.

Navidinia, H., Akar, M., \& Hendevalan, J. (2019). Using translation in language teaching: Exploring advantages and disadvantages from linguistic, humanistic and practical perspectives. International Journal of English Language and Translation Studies, 7(2), 12-18.

Nordin, N. M., Ali, F. D. R., Zubir, S. I. S. S., \& Sadjirin, R. (2013). ESL learners reactions towards code switching in classroom settings. Procedia-Social and Behavioral Sciences, 90, 478-487.

Phillipson, R. (1992). Linguistic imperialism. Oxford, Oxford University Press. Retrieved from: http://wwwhomes.uni-bielefeld.de/sgramley/Phillipson-Ling-Imperialism3.pdf

Pym, A. (2011). Translation research terms: a tentative glossary for moments of perplexity and dispute. A. Pym (ed.) Translation Research Projects 3. Tarragona: Intercultural Studies Group. 75-110.

Pym, A., Malmkjær, K., \& Gutiérrez-Colón, M. (2013). Translation and language learning: The role of translation in the teaching of languages in the European Union. Publications Office of the European Union.

Reiǵ Gascón, A. (2017). Traducción didáctica, subtitulado y TIC: proyectos en colaboración en el aula de L2. Lenguaje y textos (46), 115-124.

Sánchez Iǵlesias, J. (2009). La traducción en la enseñanza de lenguas extranjeras. Una aproximación polémica. RedELE, 10. Retrieved from: http://hdl.handle. net/10366/115934 
Siregar, M. (2019). Pedagogical Translation Use by Scientific Approach in Teaching English. Budapest International Research and Critics in Linguistics and Education (BirLE) Journal, 2(4), 111-119.

Soler Pardo, B. (2020). Subtitling and dubbing as teaching resources for learning English as a foreign language using software. Lenguaje y textos, 51, 41-56.

Swain, M. and Lapkin, S. (2000). Task-based Second Language Learning: The Uses of the First Language. Language Teaching Research, 4(3), 251-74.

Talaván, N. (2012). Justificación teórico-práctica del uso de los subtítulos en la enseñanza-aprendizaje de lenguas extranjeras. Trans (16), 23-37.

Vermeulen, A. (2004). La traducción audiovisual en la enseñanza de idiomas. Actas del Segundo Congreso Internacional, 159-168. Retrieved from: https:// biblio.ugent.be/input/download? func $=$ downloadFile $\&$ recordOId $=4211334 \&-$ fileOId $=4243423$

Vigata, H. S. (2011). Derribando barreras: el uso de subtítulos interlingüústicos en la enseñanza de lenguas. RedELE. Revista electrónica de didáctica, 21, 147-162.

Wang, X. (2014). Improving English skills through Video: A Conversation-Based Curriculum for Chinese EFL Adult Learners. Retrieved from: https://repository.usfea.edu/egi/viewcontent. cgi ? article $=1091 \&$ context=eapstone

Yavuz, F. (2012). The attitudes of English teachers about the use of L1 in the teaching of L2. Procedia - Social and Behavioral Sciences, 46, 4339-4344.

Zabalbeascoa, P., González-Casillas, S., \& Pascual-Herce, R. (2015). Bringing the SLL project to life: engaging Spanish teenagers in learning while watching foreign language audiovisuals. Subtitles and Language Learning. Ed. by Y. Gambier, A. Caimi \& C. Mariotti, 105-126.

Webgraphy

http://clipflair.net/overview/ 


\section{Annexes}

Annex 1. Pre-test

\section{PRE-TEST GROUP A / B}

NAME:

DATE:

1- Fill the gaps with the correct form of the verb: use the past simple.

1. I

2. I

3. You

(go) to the cinema yesterday.

4. (not drink) any beer last night.

4. (sit) on the president's chair.

5. $\mathrm{He}$ (feed) the ducks last night? you (not bring) the bread to the lunch!

2- Order se sentences.

6. me/for/eggs/they/dinner/some/gave

7. you/night/the salad/eat/last/didn't

8. she/try/to do/did/exercise/some/?

9. in/giraffe/there/the zoo/a/was

10. you/did/the station/at/wait/for him/?

3. Translate the following sentences.

11 . Where did that story come from?

12. The coffee was imported from Colombia.

13. She didn't know where the party was.

14. There were many books on the table.

15. The movie started five minutes ago. 
Annex 2. Preparation tutorial

\section{SUBTITLING TASK \\ PREPARATION TUTORIAL - 8 STEPS}

To work on the past simple, we are going to carry out a subtitling task this week.

1. Go to the following link: https://www.kapwing.com/

2. Click on «sign in« and the «continue with Google».

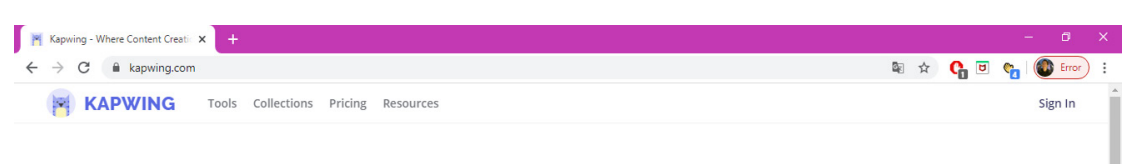

\section{Where content creation happens}

Kapwing is a collaborative platform for creating images, videos, and GIFs.
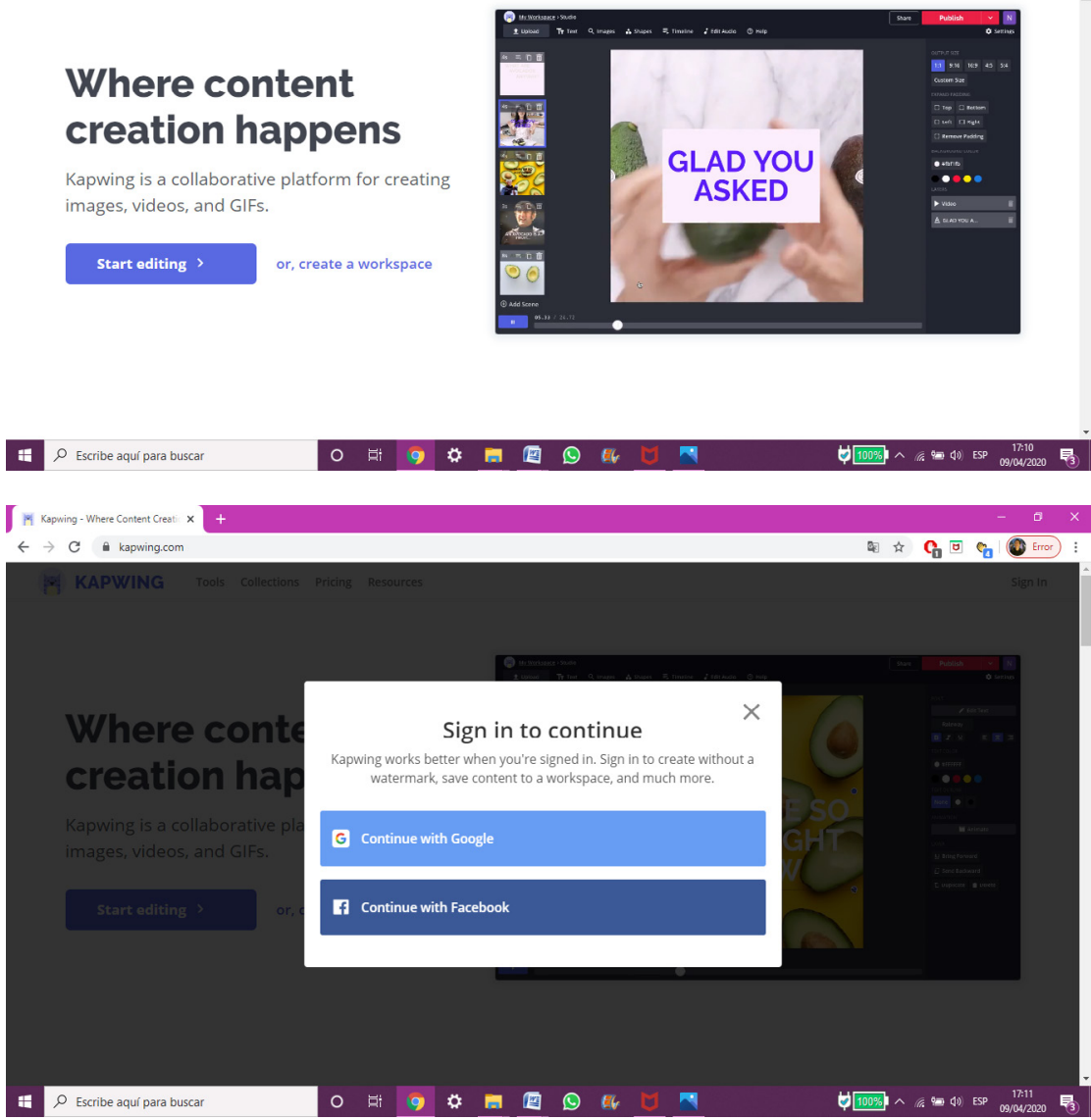
3. Once you have created your account, click on «new project».

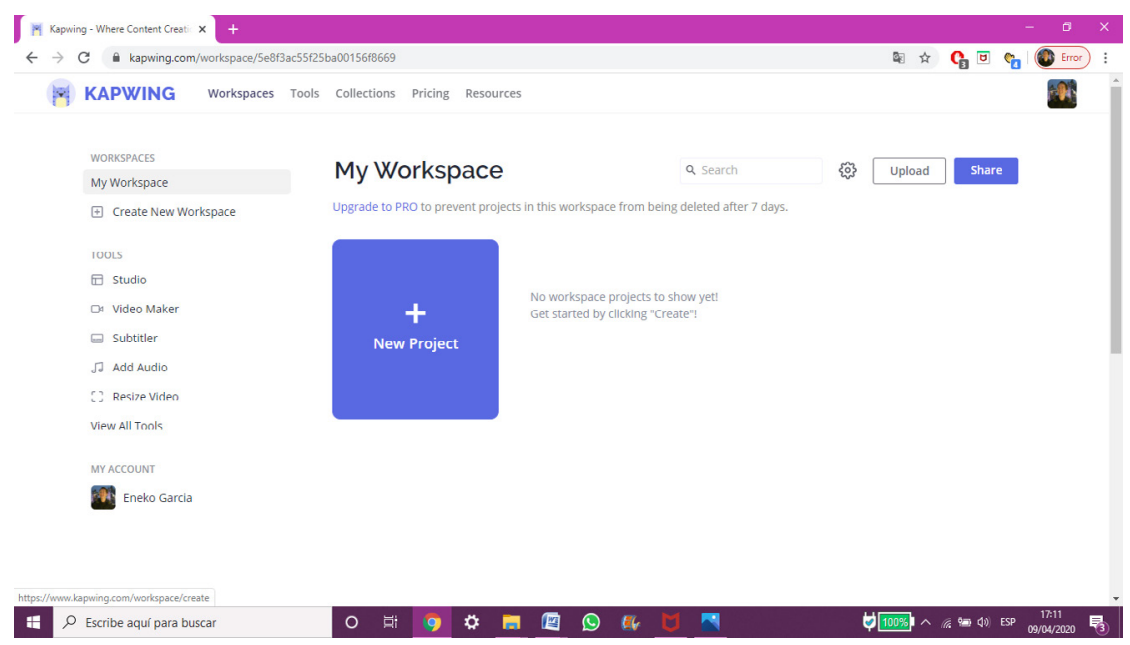

4. Click on «use a specific tool» and then on «subtitler».

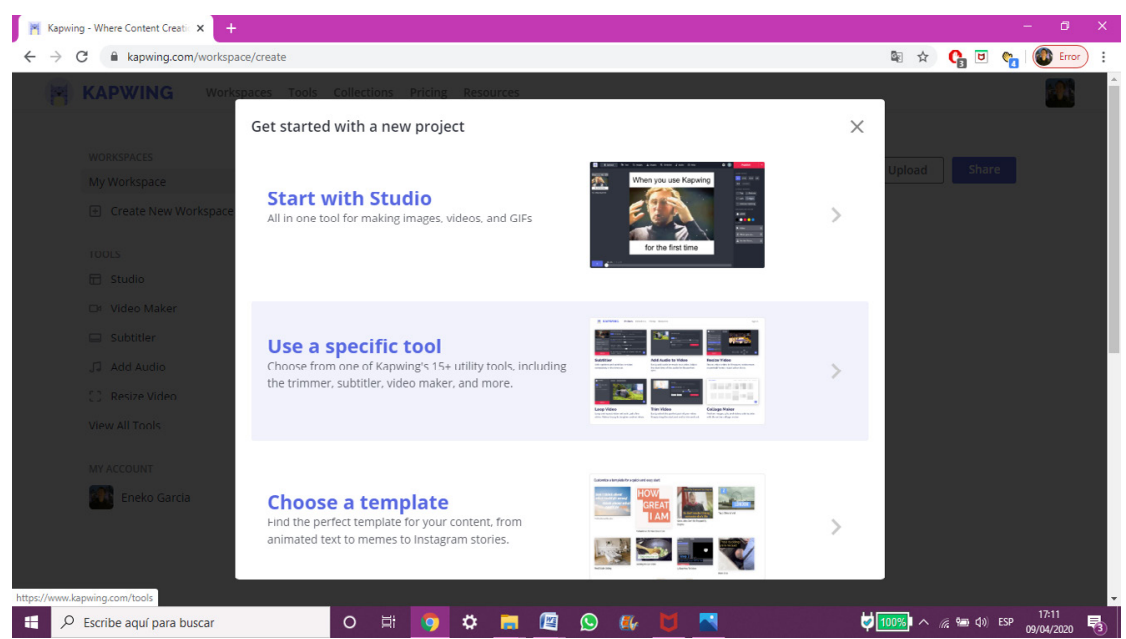




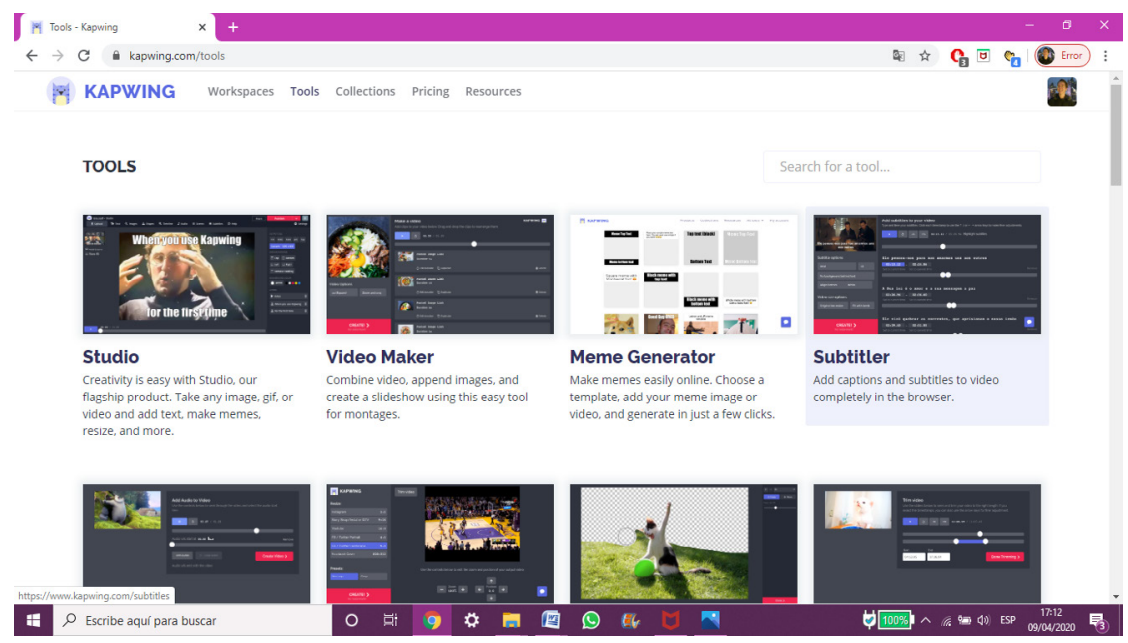

5. Now, copy and paste the following URL:

https://www.youtube.com/watch? $\mathrm{v}=\mathrm{z} 4 \mathrm{~B} 43 \mathrm{IIq}-\mathrm{Sg} \& \mathrm{t}=1 \mathrm{~s}$

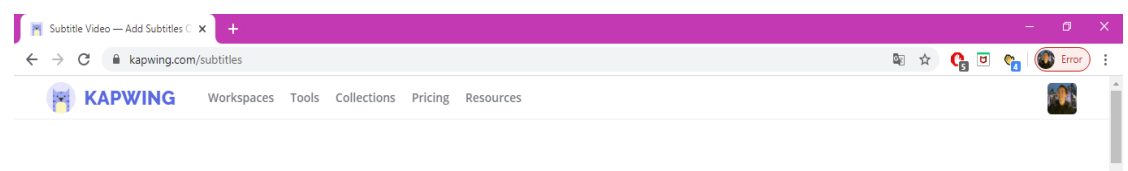

\section{Add Subtitles to Video}

Kapwing is an online editor for subtitling your videos

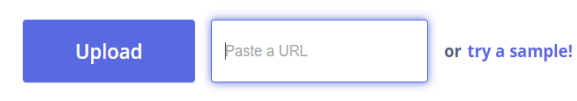

Upload or paste a link to a video to get started!

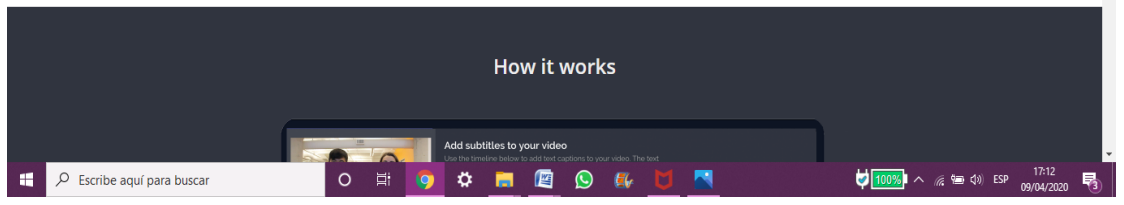


6. It's almost done! Now click on Upload.SRT and select the file that you can find HERE (you have to download the file first).
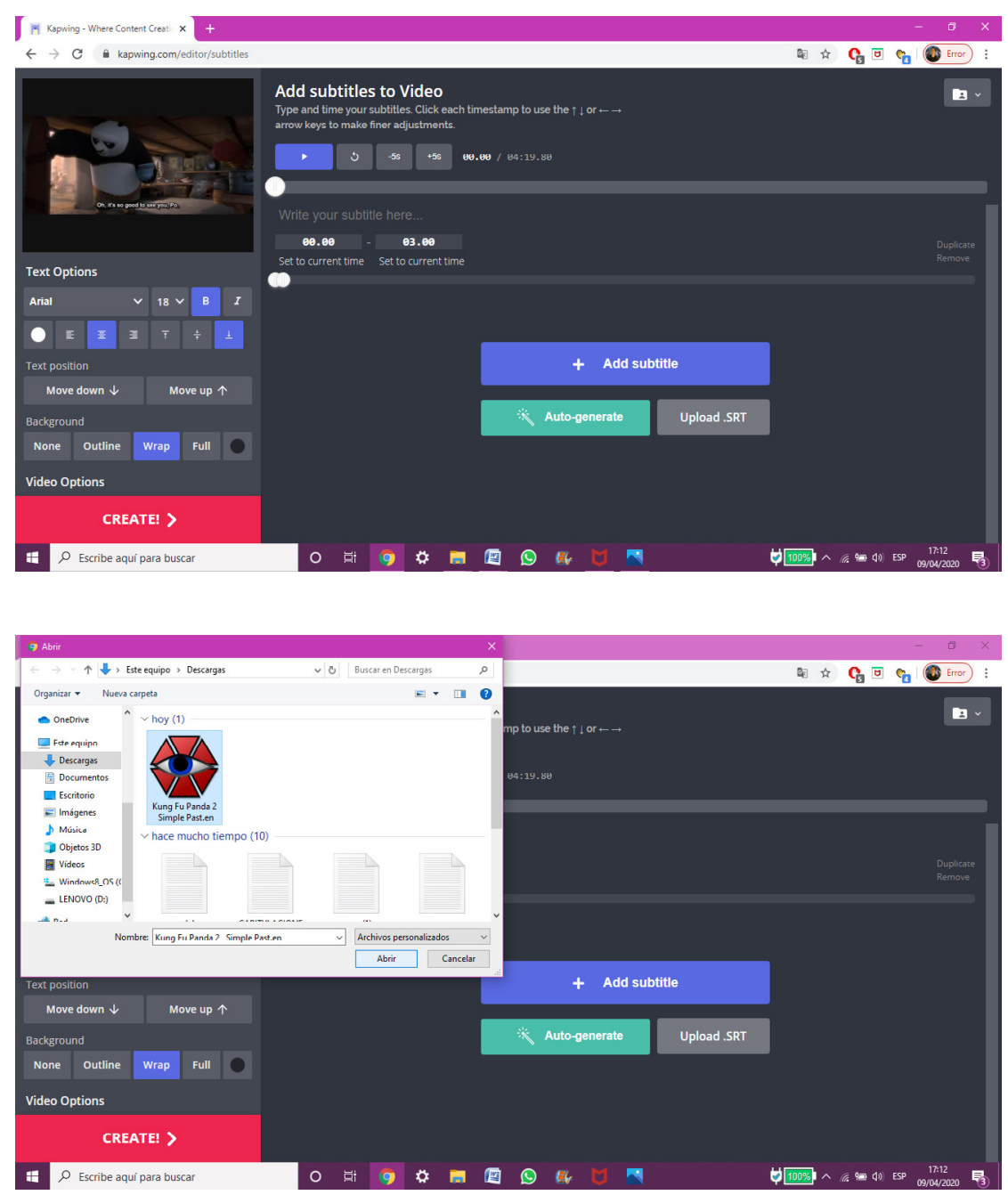


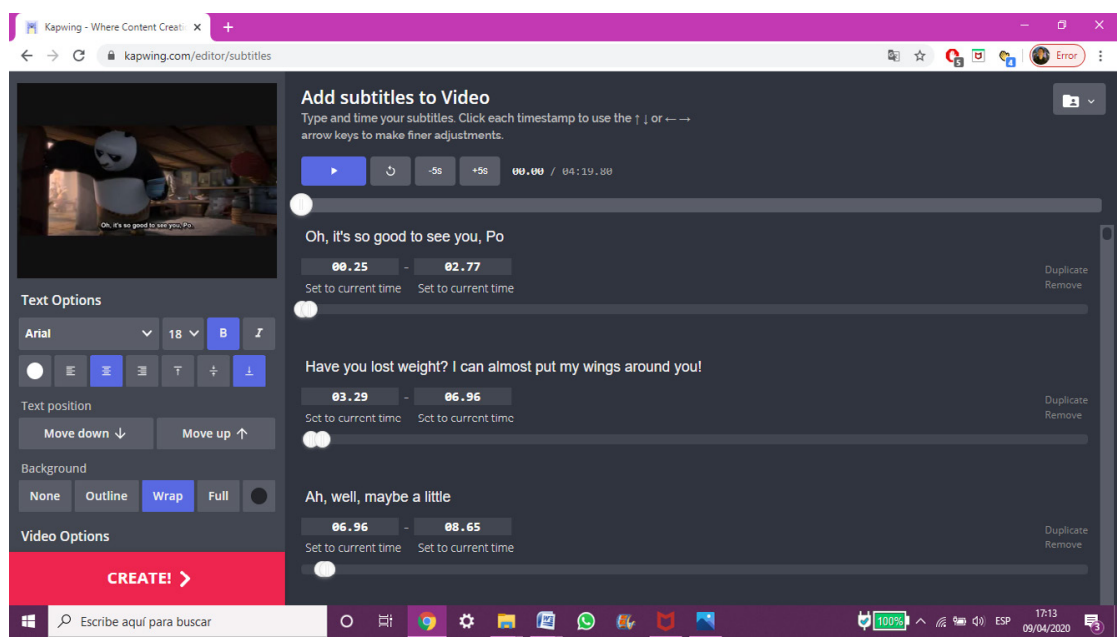

You have the English subtitles! All you have to do now is translate the English subtitles into SPANISH (BE CAREFUL! Spanish, not Basque).

\section{MY RECOMMENDATION:}

Write the subtitle in Spanish below the one in English and once you have translated it, delete the English version (as you can see in the following pictures):

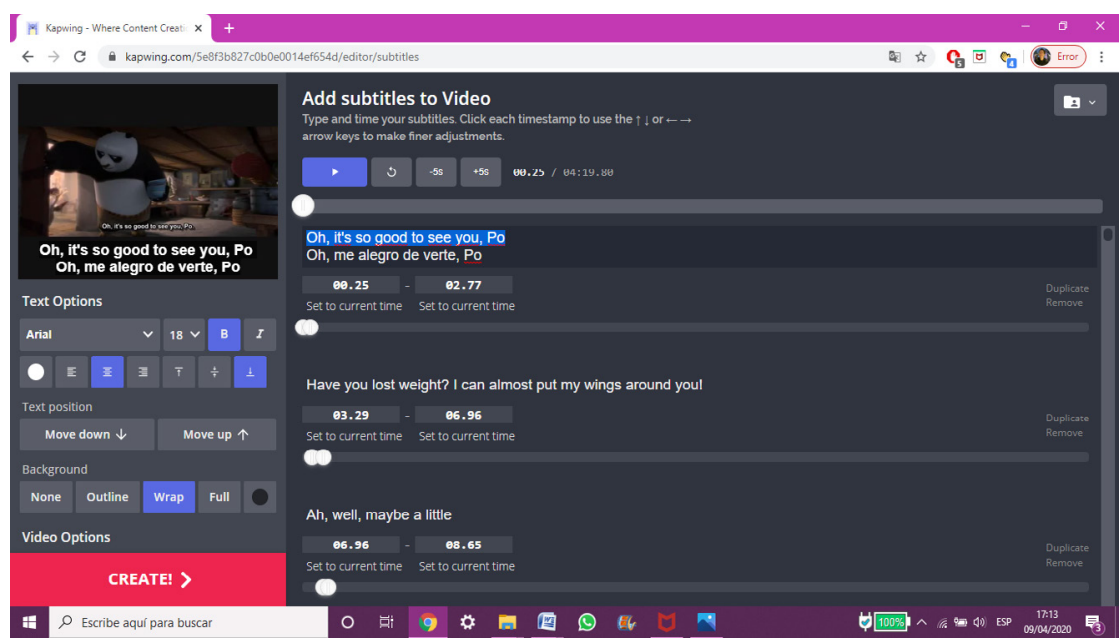


Pedagogical translation: A Didactic Proposal in the EFl Classroom to Teach Grammar by means of Subtituing

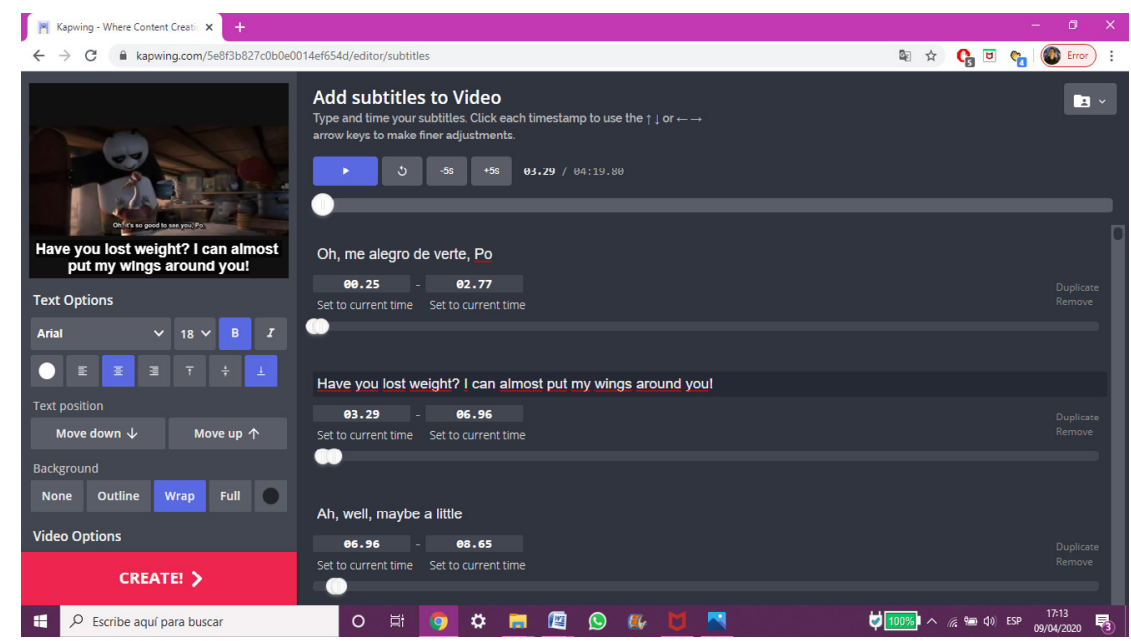

You can edit the font, size, colour, background... BE CREATIVE!

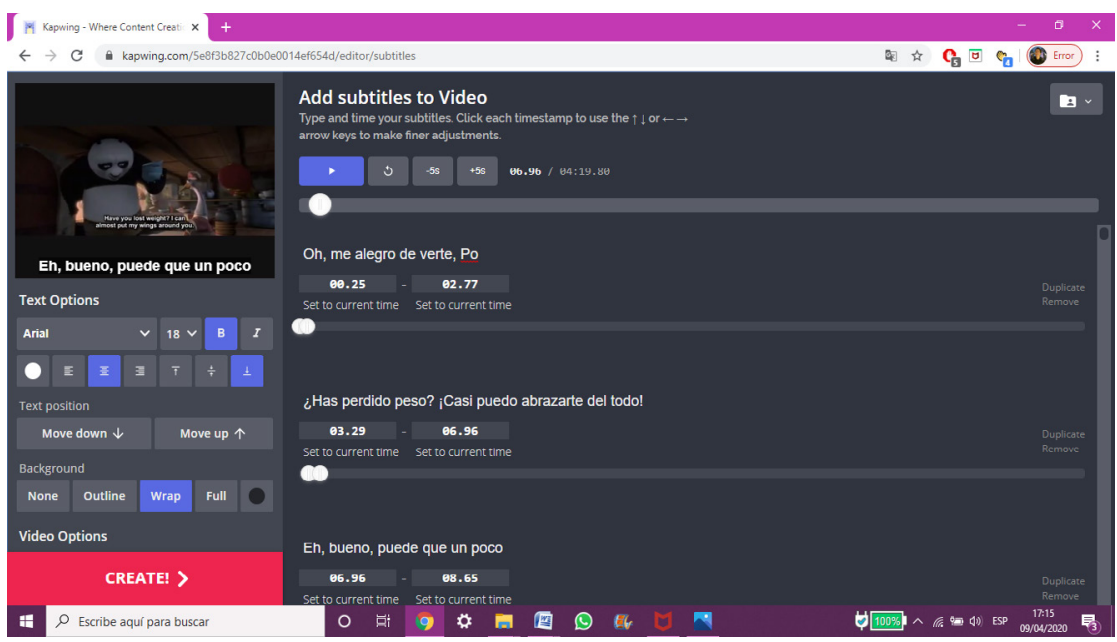


Eneko García Jaurena / Edurne Goñi Alsúa

\section{Annex 3: Finalization tutorial}

\section{SUBTITLING TASK \\ FINALIZATION TUTORIAL - $\underline{4 \text { STEPS }}$}

1. Once you have finished the translation, click on CREATE!

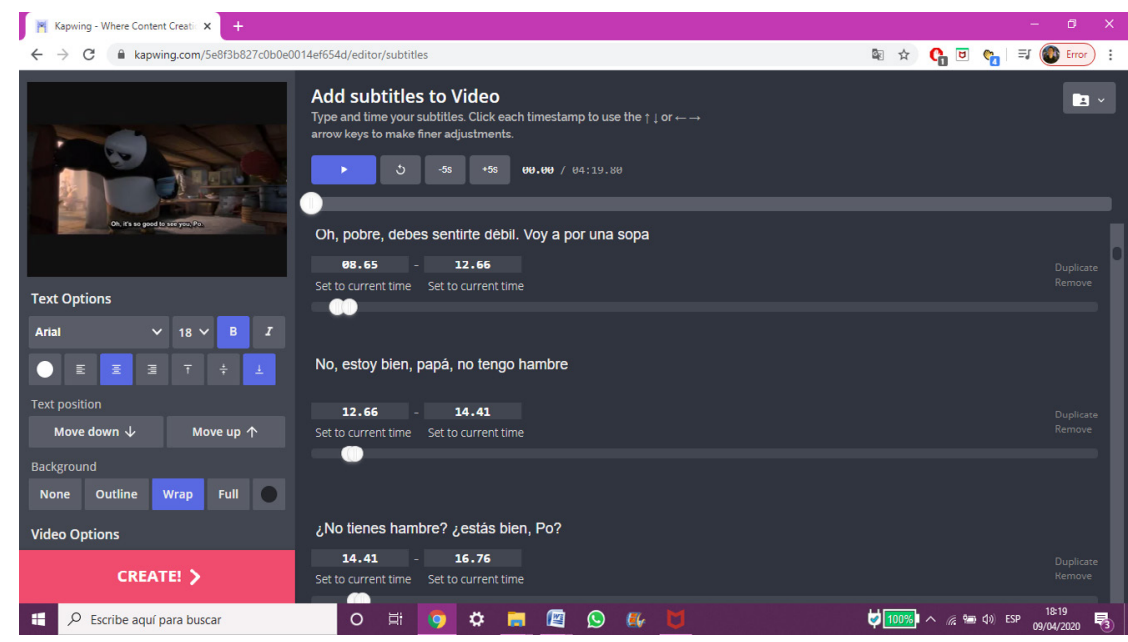

2. This page will appear now. You just have to be patient and wait. It can take some minutes to process the video.

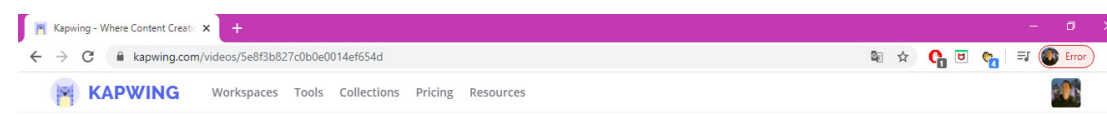

Your watermark-free content is being processed!

Weve sent your content to the Kapwing kittens, who are working as quickly as they can to create your video, image, or Gil- You can track their progress below. Please be patient, as this process can take several minutes. You can refresh this page or come back later to check on your content. 
3. Once it is finished, this page will appear. You have to click on «download» and the video will automatically start downloading.
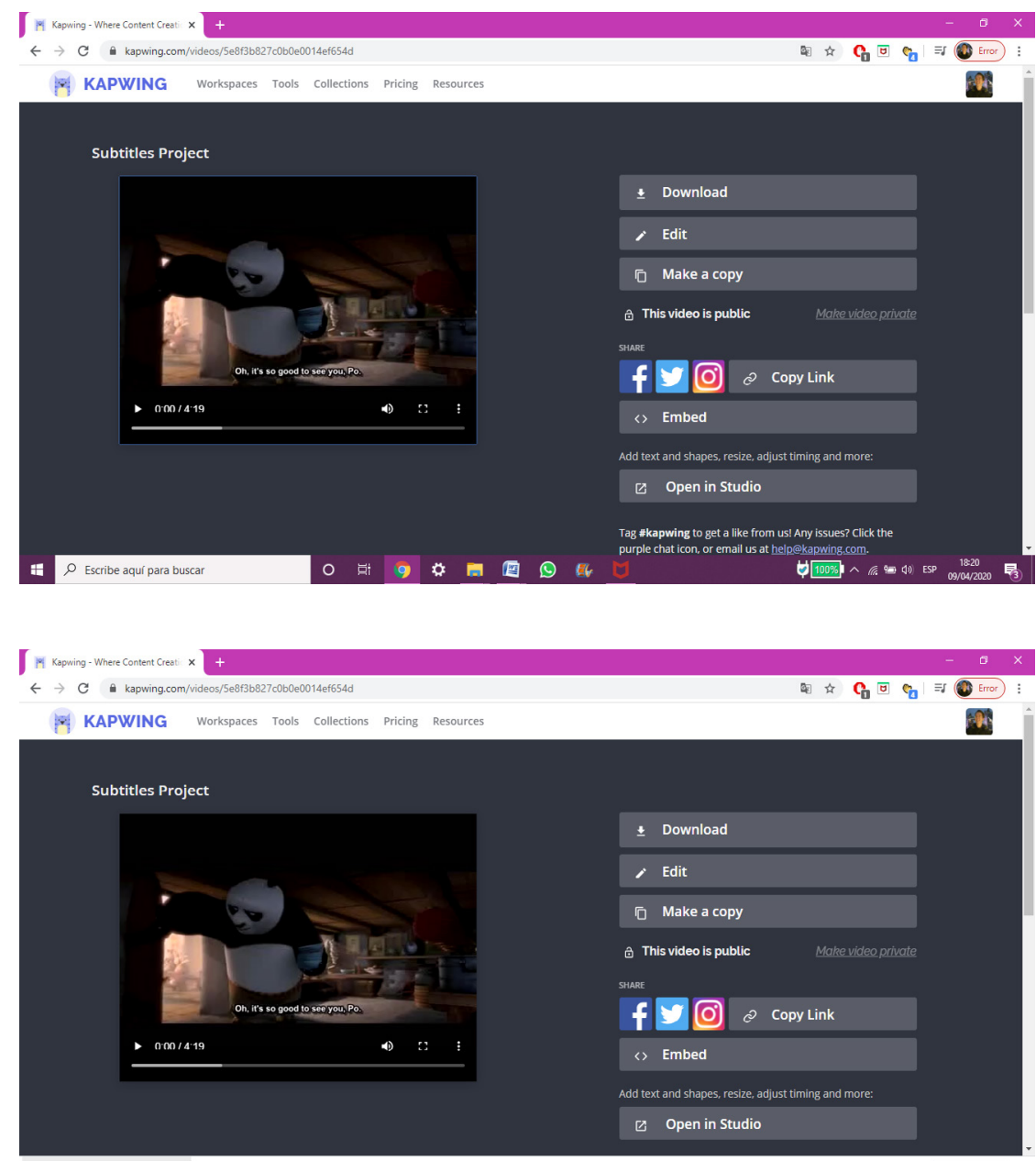

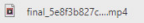

Mostrar todo $x$ H

Escribe aquí para buscar

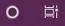
$9 \%$ 回首 ( ) E

Now:

DON'T FORGET to change the name of the file! WRITE YOUR NAME!

Upload it to Google Classroom or send it to eneko-----@gmail.com. 


\section{POST TEST GROUP A / B}

NAME:

DATE:

1- Fill the gaps with the correct form of the verb: use the past simple.

1. I (give) her my old jacket.

2. Lucas (not come) from London! It was

from Berlin!

3. My sister

4. the concert (feed) a monkey in the zoo.

5. $\mathrm{He}$ (start) on time? was difficult.

2- Order se sentences.

6. the party/Mike/go/Sunday/to/did/last/?

7. a/night/brought/Sara/last/bottle of wine

8. yesterday/buy/Mary/the newspaper/did/?

9. drank/coffee/my/a lot/yesterday/sister/of

10. many/were/in/the mall/people/there

3. Translate the following sentences.

11. The dog sat on my legs.

12. Martin waited for me at the cafeteria of the uni.

13. Sam didn't eat the fish because it was salty.

14. I didn't know the exam was today.

15. Was the tea imported from China? 
Annex 5: Questionnaire for the experimental group

\section{QUESTIONNAIRE FOR EXPERIMENTAL GROUP}

Answer the questions

1: Not at all

2: A little

3: Neutral

4: Very much

5: Absolutely

1. I like the activity:

$\begin{array}{lllll}1 & 2 & 3 & 4 & 5\end{array}$

2. Why? / Why not?

3. I would like to do more activities like this in class:
1
2
3
4
5

4. Why? / Why not?

5. I feel I have learnt / practiced the Past Simple:

$\begin{array}{llllll}1 & 2 & 3 & 4 & 5\end{array}$

6. How do you feel about using Spanish / Basque to learn English?

7. Something you would change / improve:

8. Something you would like to do / practice in class: 
Annex 6. Questionnaire for the control group

\title{
QUESTIONNAIRE FOR CONTROL GROUP
}

\author{
Answer the questions \\ 1: Not at all \\ 2: A little \\ 3: Neutral \\ 4: Very much \\ 5: Absolutely
}

1. I would like to try the subtitling task:

$\begin{array}{lllll}1 & 2 & 3 & 4 & 5\end{array}$

2. Why? / Why not?

3. I would like to do more activities like this in class: $\begin{array}{lllll}1 & 2 & 3 & 4 & 5\end{array}$

4. Why? / Why not?

5. I feel I have learnt / practiced the Past Simple:

$\begin{array}{llllll}1 & 2 & 3 & 4 & 5\end{array}$

6. How do you feel about using Spanish / Basque to learn English?

7. Something you would change / improve:

8. Something you would like to do / practice in class: 